\title{
Corporate Social Responsibility (CSR) and Risk Taking: Evidence from Indonesia
}

\author{
Rezki Ananda Mulia, Joni Joni* \\ Maranatha Christian University
}

\section{ARTICLE INFO}

\section{Article history:}

Received 13 August 2019

Revised 17 October 2019 \& 24

November 2019

Accepted 11 December 2019

Published 7 January 2020

\section{Keywords:}

CSR

Risk taking

Endogeneity

\begin{abstract}
In this paper, we investigate the effect of Corporate Social Responsibility (CSR) on risk taking in Indonesia. We hand collect CSR and other corporate governance data from 2016-2017 for publicly listed firms on the Indonesian Stock Exchange (IDX). The results, based on 820 firmyear observations, suggest that CSR activity is negatively related to corporate's risk. This means the presence of CSR activity is positively perceived by stakeholders. Therefore, it reduces operating and market risks of the company. Also, we test for endogeneity and the main findings remain similar
\end{abstract}

\section{Introduction}

The main objective of our study is to examine the relationship between Corporate Social Responsibility (CSR) and risk taking on Indonesia listed companies for the period 2016-2017.

The awareness of social and environmental issues in the society is increasing in the past few decades. Also, many businesses have paid attention on these issues lately, including the use of CSR for developing their business strategies (e.g., Hillman and Keim, 2001). In general, CSR is defined as a concept that integrates company's social and environmental goals with its business concern and its connections with stakeholders (European Commission 2010). Consistent with both legitimacy and stakeholder theories, the basic idea of CSR is a social contract in which stakeholders will support corporation's activities in providing benefits to society or at least do not harm the society (Muttakin and Khan 2014). In our study, we include community, diversity, employee relations, environment, and product characteristics as a comprehensive measure of CSR in emerging market context (Khan et al. 2013).

Strategically, CSR is used to maximize firm value and reduce company's risks. Frynas (2009) indicates that companies implement CSR for several reasons: 1) to comply with regulations, laws and rules; 2) to frame company's image; 3) as a part of company's strategy; 4) to obtain an operating license from local community. In addition, Frynas (2009) argues that CSR is a vehicle to manage corporate risk and to attract investors. For instance, several capital markets (e.g., London, Singapore, New York, and Hong Kong) apply CSR index as an indicator of investment assessment. The CSR index can be a mean to encourage global investors to invest and to identify company's risk. Faccio, Marchica and Mura (2011) show that risk management can maintain the company's long-term growth in the context of European firms. Therefore, CSR activity is used to gain legitimacy and to communicate with stakeholders in order to build a reputation and to minimize risk based on manufacturing companies in Germany (Zhang 2016).

Further, Salama et al. (2011) investigate the association between social and environmental performance and systematic risk. Based on large sample of U.K. companies from 1994 to 2006, they find that social and environmental

* Corresponding author.

E-Mail address:.joni@eco.maranatha.edu 
performance is negatively related to firm's systematic risk. Jo and Na (2012) test the effect of corporate social responsibility on firm's risk in the U.S. controversial industry sectors from 1991 to 2010. In line with the riskreduction hypothesis, they find that CSR activities reduce a negative impact of controversial firms (such as alcohol, tobacco, and gambling). Consequently, the presence of CSR strategy is negatively associated with firm risk (systematic and unsystematic risks). Also, they control for endogeneity problem using the 3SLS estimation. Recently, Harjoto and Laksmana (2016) provide a new perspective by examining the relation between CSR on both excessive risk-taking and excessive risk avoidance (managerial decision on risk taking) in U.S. from 1998-2011. They show that CSR performance reduce the level of risk taking. This finding is consistent with stakeholder theory suggesting that CSR is a control mechanism to satisfy the interest of investing stakeholders (shareholders) and non-investing stakeholders. However, Ayadi et al. (2014) find that U.S. companies with better CSR performance result in a higher degree of risk taking compared to companies with lower CSR performance. They indicate that several CSR dimensions (e.g., employee relations, product characteristics, and diversity) are positively associated with risk taking. Nguyen and Nguyen (2015) show that U.S. firms with better CSR implementation experience higher company's risk. Based on the empirical evidence discussed, the findings on the association between CSR and company's risk are mixed and inconclusive, especially in emerging market context. While several studies examine the association between CSR and corporate risks based on U.S. and other European samples, studies on this association in emerging market, including Indonesia are still scarce. Our study fills this void and provides evidence from emerging country perspective which has different institutional setting compared to the evidence from developed country settings.

The implementation of CSR in Indonesia is formally regulated, yet the awareness is still low. According to Company Law No.40 of 2007 Article 74 paragraph 1, a Limited Liability Company operating in the area and / or concerned with natural resources must conduct environment and social responsibility. Further, Act No. 25 of 2007 Article 15 (b) states that investor is obligated to conduct corporate social responsibility. Specifically, Company Law No.40 of 2007 Article 66 paragraph 2 states that all companies are obligated to report their CSR activities in the annual report. Meanwhile, the regulators show the importance of CSR, the implementation is still far from their expectation. The performance of Indonesian listed companies is far behind compared to other countries (Asian or Western counties). In the Asian context, based on Global Reporting Initiative (GRI) indicators, Centre for Governance, Institutions and Organisations (CGIO) (2016) shows that Thailand obtains the highest score in terms of CSR implementation with a value of 56.8 out of 100, while Singapore has 48.8. The score for each Indonesia and Malaysia is 48.4 and 47.7, respectively. Further, Global CSR Rap Trak (2017) reports that most of the US companies (45 companies) is nominated in the top 100 Most Socially Reputable Companies, and 24 companies are from Asian countries (Japan: 12 companies; South Korea: 12 companies).

Based on the research background and motivation mentioned earlier, we examine whether CSR activities are associated with risk taking in Indonesian listing companies. We expect that the finding of this paper provides a better understanding on how company distributes their resources to stakeholders in emerging market context (Harjoto and Laksmana, 2018). Also, it contributes to the literature by addressing the conflicting results and showing an empirical evidence on the influence of CSR on risk taking in Indonesia where the awareness of CSR is still insignificant and the level of risk is higher compared to developed market. Further, our finding provides additional information for investors on the importance of CSR to reduce corporate risks and for policy makers to develop better policies regarding to CSR practices.

\section{Literature Review and Hypothesis Development}

The Legitimacy theory states that organisations continuously ensure their activities to support community. It assumes that the actions taken by an organisation are desirable, appropriate or in accordance with the system, norms, values, beliefs and socially developed definitions. Gray et al. (1996) argue that legitimacy is a management system which provides supports to society, government, individuals and community groups. Consequently, company's operations should be in line with community's expectation. When organization complies with government regulations and social norm, it will reduce organization's risks and increase their reputation (Deegan 2002). The stakeholder theory further suggests that organizations must pay attention to stakeholders because it can influence company's going concern. Heal and Garret (2005) show that CSR activities can be a corporate strategy which maintain the relationship between corporation and stakeholders. This relationship might provide long-term benefits for the company, and contribute to the risk management process. In the perspective of stakeholder theory, CSR activities can benefit companies by lowering company's risk (Donaldson and Preston 1995; Jones 1995). CSR activities also help firms to survive and become more resilient in a crisis time. Practically, CSR activities establish a group of goodwill that will reduce a negative impact from stakeholder assessments (Sen et al., 2006). For instance, CSR activities increase customer's 
loyalty, improve employee's attitude, develop a strong safety's culture, and pay full attention to the stakeholder's interests. As a result, CSR activities will reduce the corporate's risks.

Empirically, there is a growing literature on how CSR activities reduce firm's risks in developed countries. Harjoto and Laksmana (2018) stated that CSR involvement is not always about wealth or resources transfer from shareholders to stakeholders, yet CSR might reduce both insufficient and excessive risks that have a detrimental impact on the value of the firm value and shareholder value in U.S. context. Salama et al. (2011) find a negative association between environmental and social performance, and corporation's systematic risk based on U.K. listed firms. In addition, Jo and $\mathrm{Na}$ (2012) find that CSR is negatively associated with the volatility of stock returns in U.S. listed firms. Recently, Chollet and Sandwidi (2018) examine the effect of CSR engagement and firm's financial risk using international sample from 2003 to 2013, except Indonesia. They contribute to the literature by finding a negative association between CSR engagement and firm's risk based on large sample. In addition, they utilize panel vector autoregressive (VAR) along with GMM estimation to test the causal effect between CSR and firm's risk. Chakraborty, Gao, and Sheikh (2019) investigate whether CSR affects firm's risk. Also, they explore whether CSR influence the relation between vega of CEO compensation and firm's risk. By using 1,947 large US companies from 2003-2015, they find that CSR activity reduce the level of firm's risk. Moreover, the relation between vega of CEO compensation and firm's risk is negative when CSR is negative in low CSR companies and it has no effect in high CSR companies. It means that companies maximize stakeholder's interests when firms have high CSR performance. However, several studies in the U.S. context find a positive direction on the effect of CSR and firm's risk (Ayadi et al., 2014; Nguyen and Nguyen, 2015). In other words, firms are riskier when they implement CSR. Thus, the empirical studies on this association were inconsistent and mixed.

While most studies examine the relationship between CSR activity and corporate's risk in the context of developed countries and the findings are inconclusive, limited studies investigate whether CSR is an effective vehicle to minimize corporate's risks in emerging market context, such as Indonesia where the law enforcement is low and the level of risk is high (Khan et al., 2012). There are various factors (macro and micro levels) to consider that corporate risk in Indonesia is different compared to developed countries, including high level of inflation rate, poverty and unemployment rate; a heavily depreciating currency exchange rate; political instability; the poor performance of corporate governance; and a poor safety culture. Therefore, to study the association between CSR and firm's risk in this context is important.

Based on prior theoretical framework and the empirical research above, we propose the following hypotheses:

H1a: CSR activities in Indonesia are associated with the corporate operational risk taking.

H1b: CSR activities in Indonesia are associated with the corporate market risk taking.

\section{Research Design}

We use panel data with 434 non-financial listed companies in the Indonesian Stock Exchange (IDX) for the period 2016-2017. Purposive sampling is utilized in our study with several criteria: (1) all listed companies in the IDX, except financial service companies. This is due to financial service companies are under different regulations and financial reporting structures; (2) all companies disclose its 2016-2017 annual reports. After checking the required industries and eliminating the missing data, the final sample of this study is 820 firm-year observations. The detail of our sample selection is described in Table 1.

Table 1. Description of the sample

\begin{tabular}{lccc}
\hline Calendar Year & $\mathbf{2 0 1 6}$ & $\mathbf{2 0 1 7}$ & Panel \\
\hline Number of listed companies & 539 & 555 & 1.094 \\
Number of firms from financial industry & 105 & 121 & 226 \\
Number of observations with missing data. & 27 & 21 & 48 \\
Number of firm in the sample & 407 & 413 & $\mathbf{8 2 0}$ \\
\hline
\end{tabular}


To test the effect of CSR on risk taking, we estimate the following baseline empirical model:

$\mathrm{Y}=\alpha+\beta 1 \mathrm{CSR}+\beta 2 \mathrm{LEV}+\beta 3 \mathrm{GROWTH} \_\mathrm{SALES}+\beta 4 \mathrm{LNTA}+\beta 5 \mathrm{FAGE}+\beta 6 \mathrm{~F} \_$BODSIZE $+\beta 7 \mathrm{~F}$ INDBOD $+\varepsilon$

Following extant studies in emerging market (Khan et al., 2012; Harjoto and Laksmana, 2018), we use CSR index to measure CSR (independent variable), including five dimensions: community, diversity, employee relations, environment, and product characteristics. The CSR index consists of 20 indicators. We score 1 if a company implements CSR in each item, and 0 if otherwise. Then, the score of each item is summed to obtain the CSR index of each company. The detail of CSR indicators is provided in Table 2.

Table 2. CSR indicators

\section{CSR Indicators}

\section{Community involvement}

- Charitable donations and subscriptions

- Sponsorships and advertising

- Community program (health and education)

\section{Environmental}

- Environmental policies

\section{Product and service information}

- Types of products disclosed

- Product development and research

- Product quality and safety

- Discussion of marketing network

- Focus on customer service and satisfaction

- Customer award / rating received

\section{Value added information}

- Value added statement

We apply two measures to proxy corporate risk taking as our dependent variable. The first measure is STDROA defined as a standard deviation of return on assets. This variable measures management decisions on corporate operational risk taking. Following Harjoto and Laksmana (2018); and Acharya et al. (2011), STDROA is measured as the standard deviation of industry adjusted return on assets (ROA), where ROA is earnings after interest and taxes divided by assets. We require at least 5 years of ROA data (e.g., t- 4 to t) to compute the standard deviation of ROA. The second measure of risk taking is VOL (volatility) of stock returns considered as the market risk measure. Following previous studies (e.g., John et al., 2008; Acharya et al., 2011; Bova and Pereira, 2012; Faccio et al., 2011; Harjoto and Laksmana, 2018), VOL is measured by using standard deviation of daily stock returns for the fiscal year.

We include board characteristics as control variables, such as the number of female directors (F_BODSIZE) and the number of independent female directors (F_INDBOD) by following previous studies. For instance, Pandey et al (2018) and Abbott et al., (2012) argue that the increased number of female director result in better performance in risk monitoring and risk management. This is due to female directors are more independent and selective in risk taking. Bradley and Chen (2014) find that independent female directors lower corporate risks that will benefit shareholders. Leverage (LEV) measures how much a company is financed by debt. Harjoto and Laksmana (2018) indicates that debt is associated with firm's risk. We also control firm size (LNTA) and firm age (FAGE) in this study. Nguyen (2012) shows that a company's age reduces risk taking. Lastly, we control sales growth (SALES_GROWTH). John et al. (2008) explain that the sales growth of US-registered manufacturing companies is positively related to risk taking. Table 3 shows detailed descriptions of all the variables used in this paper. 
Table 3. Variable Definitions and Acronyms

\begin{tabular}{|c|c|}
\hline Variable & Definition \\
\hline CSR & $\begin{array}{l}\text { CSR Index = the total score of the item disclosed divided by the number of items for the } \\
\text { company (Khan, Mohammad and Javed , 2012; Muttakin and Khan, 2014) }\end{array}$ \\
\hline SDROA & $\begin{array}{l}\text { The standard deviation of industry-adjusted ROA (e.g., earnings after interest and taxes } \\
\text { divided by assets). At least five years of data (e.g., t-4 }\end{array}$ \\
\hline & to $t$ ) is required to compute the standard deviation (Harjoto and Laksmana, 2018). \\
\hline VOL & $\begin{array}{l}\text { The standard deviation of the daily stock returns for year t (Harjoto and Laksmana, 2018; Jo } \\
\text { and } \mathrm{Na}, 2012 \text { ) }\end{array}$ \\
\hline \multicolumn{2}{|l|}{ Control Variable } \\
\hline LEV & Total long term debt divided by the total assets (Usman, et.al. 2018) \\
\hline GROWTH_SALES & (Sales year $\mathrm{t}$ - sales year t-1) divided by sales year $\mathrm{t}-1$ (Harjoto and Laksmana, 2018). \\
\hline LNTA & Natural log of total Assets. (Nguyen and Nguyen, 2015) \\
\hline FAGE & $\begin{array}{l}\text { Year of Research }(2018) \text { reduced by years since listing on the Indonesia Stock Exchange } \\
\text { (IDX) (Bliss and Gul, 2012) }\end{array}$ \\
\hline F_BODSIZE & $\begin{array}{l}\text { The number of female directors on the board of directors (Terjesen, Eduardo and Paulo, } \\
\text { 2015). }\end{array}$ \\
\hline F_INDBOD & The number of female directors divided by the total director members. (Usman et. al., 2018) \\
\hline
\end{tabular}

\section{Empirical Results}

Table 4 provides descriptive statistics of the main variables with a sample of 820 observations to test the relationship between CSR and risk, including minimum, maximum, mean and standard deviation values. In addition to the dummy variable, all variables are analysed at the $2^{\text {nd }}$ and $98^{\text {th }}$ percentiles. The minimum (maximum) value for SDROA is 0.001 (1.147), the average value is 0.097 and the standard deviation value is 0.192 . The minimum value (maximum) for VOL is 0 (0.07), the average value is 0.029 and the standard deviation value is 0.016 . The minimum value (maximum) for CSR is 0 (0.95), the average value is 0.606 and the standard deviation value is 0.183 . The results of the descriptive statistics for the SDROA, VOL, and CSR variables are consistent with the previous studies by Harjoto and Laksmana (2018).

Table 4. Summary Statistics of Main Variables

\begin{tabular}{cccccc}
\hline Variable & Observation & Minimum & Maximum & Mean & Std. Deviation \\
\hline SDROA & 820 & 0.001 & 1.147 & 0.097 & 0.192 \\
VOL & 820 & 0 & 0.07 & 0.029 & 0.016 \\
CSR & 820 & 0 & 0.95 & 0.606 & 0.183 \\
LEV & 820 & 0.002 & 0.87 & 0.200 & 0.191 \\
GROWTH_SALES & 820 & -0.909 & 4.033 & 0.152 & 0.711 \\
LNTA & 820 & 20.859 & 33.32 & 28.426 & 1.838 \\
FAGE & 820 & 1 & 38 & 16.007 & 9.404 \\
F_BODSIZE & 820 & 0 & 5 & 0.654 & 0.918 \\
F_INDBOD & 820 & 0 & 0,5 & 0.033 & 0.092 \\
\hline
\end{tabular}


Notes: The table presents the summary statistics of the main variables. The sample includes 820 firm-year observations for the period 2016-2017. All variables are based on calendar year. Variable definitions: CSR is the CSR index consist of 20 indicators. We score 1 if company implements CSR in each item, and 0 otherwise. Then the score of each item will be summed to obtain the CSR index of each company. SDROA is the standard deviation return on assets for firm operational risk taking, where ROA is calculated as earnings after interest and taxes divided by assets. At least 5 years of ROA data are required to compute the standard deviation of ROA. VOL is the volatility of stock returns for firm market risk taking. We measure VOL by using standard deviation of daily stock returns for the fiscal year. SALES_GROWTH is (Sales year $\mathrm{t}$ - sales year t-1) divided by sales year t-1. LEV is total long-term debt divided by the total assets. LNTA is the natural logarithm of total assets. FAGE is the number of year study reduce by number of years since the firm was established. F_BODSIZE is the number of female directors on the board of directors. F_INDBOD is the number of female directors divided by the total director members.

Table 5 reports the results of correlation test using the Pearson product moment. The highest correlation is between the F_INDBOD and F_BODSIZE variables with a value of 0.413 which means that the relationship between F_INDBOD and F_BODSIZE is quite strong and in the same direction (the higher the F_INDBOD, the higher the F_BODSIZE). The correlation between F_BODSIZE and CSR is 0.171 , which means that the relationship between F_BODSIZE and CSR is very low and unidirectional (the higher the F_INDBOD, the higher the CSR). the correlation between CSR and VOL is 0.108 which means that the relationship between CSR and VOL is very low and in the opposite direction (the higher the CSR, the lower the VOL).

Table 5. Correlation matrix

\begin{tabular}{|c|c|c|c|c|c|c|c|c|c|}
\hline & 1 & 2 & 3 & 4 & 5 & 6 & 7 & 8 & 9 \\
\hline SDROA (1) & 1.000 & & & & & & & & \\
\hline VOL (2) & $0.006^{*}$ & 1.000 & & & & & & & \\
\hline CSR (3) & $-0.061 * * *$ & $-0.108 * * *$ & 1.000 & & & & & & \\
\hline LEV (4) & $0.102 * * *$ & $-0.045^{* *}$ & $-0.025^{* *}$ & 1.000 & & & & & \\
\hline GROWTH_ & $0.062 * * *$ & $0.080 * * *$ & $-0.074 * * *$ & $-0.005^{*}$ & 1.000 & & & & \\
\hline \multicolumn{10}{|l|}{ SALES (5) } \\
\hline LNTA (6) & $-0.039 * *$ & $0.004 *$ & $-0.017 * *$ & $-0.022 * *$ & $0.001^{*}$ & 1.000 & & & \\
\hline FAGE (7) & $-0.033 * *$ & $0.060 * * *$ & $-0.103 * * *$ & $-0.095 * * *$ & $-0.064 * * *$ & $0.033 * *$ & 1.000 & & \\
\hline F_BODSIZE (8) & $-0.006^{*}$ & $-0.074 * * *$ & $0.170 * * *$ & $0.066^{* * *}$ & $-0.035^{* *}$ & $0.001 *$ & $-0.065 * * *$ & 1.000 & \\
\hline F_INDBOD (9) & $0.015 * *$ & $-0.045^{* *}$ & $0.066^{* * *}$ & $-0.092 * * *$ & $0.015 * *$ & $-0.021 * *$ & $-0.107 * * *$ & $\begin{array}{l}0.412 * * \\
*\end{array}$ & $\begin{array}{l}1.00 \\
0\end{array}$ \\
\hline
\end{tabular}

The table reports the pairwise Pearson correlation matrix for the full sample ( 820 firm-year observations). Please see Table 3 for definitions of variables. $*, * *, * * *$ indicate two-sided significance at the $1 \%, 5 \%$, and $10 \%$ levels, respectively.

Table 6 presents the regression result on the association between CSR and risk taking. Model 1 shows that CSR is negatively associated with operational risk taking at the $10 \%$ level (coefficient $=-0.071 ; \mathrm{t}=-1.93$ ). Therefore, hypothesis 1a which states that "CSR activities in Indonesia are associated with the corporate operational risk taking" is accepted. This finding is consistent with Harjonto and Indrarini (2018).

SDROA $=0.225-0.071 \mathrm{CSR}+0.102 \mathrm{LEV}+0.018$ GROWTH_SALES - 0.004LNTA + 0,000 FAGE 0.001F_BODSIZE + 0.065F_INDBOD + e 
CSR is a form of social responsibility carried out by the company. The main objective of CSR is to maximize the positive impact on the company and minimize the operational risk of the company (SDROA). The benefits of implementing CSR is to consistently increase profitability by reducing risk. In addition, CSR helps companies to reduce inefficiencies in production that will eliminate operational costs and risks. Thus, CSR can be used as a vehicle to minimize operational risk (SDROA).

Model 2 shows that the effect of CSR on market risk taking is negative and significant at the 5\% level (coefficient $=-0.007 ; \mathrm{t}=-2.32$ ). Hypothesis $1 \mathrm{~b}$ which states that "CSR activities in Indonesia are associated with the corporate market risk taking" is supported. This finding is consistent with previous studies (Jo and Na, 2012; Harjonto and Indrarini, 2018).

$\mathrm{VOL}=0,035-0,007 \mathrm{CSR}-0,003 \mathrm{LEV}+$ 0,002GROWTH_SALES - 0,000LNTA + 0,000 FAGE 0,001F_BODSIZE - 0,002F_INDBOD + e

CSR is an important mean to improve the company's reputation and lower market risk. CSR can strengthen the company's brand through community. By having loyal community, the company becomes more attractive. Further, community satisfaction on CSR will ultimately cause better profitability. This means public will trust a company's products (goods or services). Also, investors are interested in companies with better CSR performance. Consequently, it can attract more investors and reduce market risk. Market risk is caused by fluctuations of the market and other events that occur beyond management's control and investors as a whole can affect the return of an investment.

Table 6. CSR and Risk Taking-Pool OLS Regression

\begin{tabular}{lcc}
\hline & Model 1 (SDROA) & MODEL 2 (VOL) \\
\hline CSR & $-0.071^{*}$ & $-0.007^{* *}$ \\
& $(-1.93)$ & $(-2.32)$ \\
LEV & $0.102^{* * *}$ & -0.003 \\
GROWTH_SALES & $(2.87)$ & $(-1.08)$ \\
& $0.018^{*}$ & $0.002^{* *}$ \\
LNTA & $(1.93)$ & $(2.22)$ \\
& -0.004 & -0.000 \\
FAGE & $(-1.18)$ & $(-0.34)$ \\
F_BODSIZE & 0.000 & 0.000 \\
& $(0.05)$ & $(1.52)$ \\
F_INDBOD & -0.001 & -0.001 \\
& $(-0.12)$ & $(-1.07)$ \\
Intercept & 0.065 & -0.002 \\
& $(0.82)$ & $(-0.23)$ \\
year and industry & $0.225^{* *}$ & $0,035^{* * *}$ \\
Observation & $(2.12)$ & $(3.90)$ \\
R-squared & Included & Included \\
\hline
\end{tabular}

The table reports OLS coefficient estimates and dummy variables that are included in the regression to control for year and industry differences. However, the results are not provided due to space constraints. All definitions of variables are listed in Table 3. *,**, *** indicate two-sided significance at the $1 \%, 5 \%$, and $10 \%$ levels, respectively. 


\section{Discussion}

The main purpose of this paper is to empirically test the effect of CSR activity on risk taking in Indonesia. To address this research question, we use CSR index developed by Khan et al. (2012), since it is designed and widely used for emerging market context. Then, by following Harjoto and Laksmana (2018), our study utilizes the standard deviation of industry adjusted return on assets to measure operating risk and the volatility of stock return to calculate market risk. OLS regression is used to estimate this association. Initially, our finding shows a negative relationship between CSR and risk taking suggesting that CSR engagement reduces the level of risk in emerging market where the law enforcement is weak.

Our finding is consistent with both Legitimacy and Stakeholder theories suggesting that organization's risks can be reduced when they actively consider social norms and their stakeholders. Also, the finding of this study is empirically supported by previous studies. For instance, after controlling endogeneity issue, Jo and Na (2012) find that CSR strategy eliminates corporate risks in the context of U.S. controversial industry sectors. Similarly, Salama et al. (2011) examine the effect of CSR performance and firm's risk in U.K. and show that firms with higher CSR performance experience lower systematic risks. Further, Harjoto and Laksmana (2018). report a negative association between CSR activity and excessive risk taking and risk avoidance based on the sample of U.S. firms.

Overall, we provide additional understanding on the relationship between CSR and corporate's risk in the context of emerging market. It is clearly shown that CSR can be an important strategy to reduce operating and market risks in Indonesia. We contribute to the growing literature by providing an empirical evidence on the effect of CSR on risk in emerging market context. Our study also provides an implication for investors when considering the effect of CSR on risk taking in emerging market. Finally, our study helps policy makers to consider more incentives for listed companies to improve the implementation of CSR in Indonesia.

Further work needs to address the effect of CSR and corporate risk in controversial industry sectors (e.g., tobacco, alcohol, adult entertainment) in the context of emerging market (Jo and $\mathrm{Na}, 2012$ ). It is interesting to investigate whether firms that produce harmful products use CSR as a tool to manage risks and to improve their corporate image. Another further studies should consider the mediating effect of risk management on the relationship between CSR and firm value in emerging market (Harjoto and Laksmana, 2018).

\section{Sensitivity Tests}

Endogeneity problem is addressed in our sensitivity test using the general moment method (GMM). GMM can be applied to deal with heteroscedasticity in the model. Table 7 shows the results of the GMM test in models 1 and 2. Overall, these results are consistent with the main results in Table 6, which indicate CSR variables are negatively significant with company's operating and market risks.

Table 7. CSR and Risk Taking-GMM model

\begin{tabular}{lcc}
\hline & Model 1 (SDROA) & Model 2 (VOL) \\
\hline CSR & $-0.061^{*}$ & $-0.081^{* *}$ \\
& $(-1.68)$ & $(-2.45)$ \\
LEV & $0.099^{*}$ & -0.004 \\
GROWTH_SALES & $(1.77)$ & $(-1.03)$ \\
& 0.018 & 0.002 \\
LNTA & $(1.01)$ & $(1.57)$ \\
& -0.005 & -0.000 \\
FAGE & $(-1.23)$ & $(-0.06)$ \\
& 0.000 & 0.000 \\
F_BODSIZE & $(0.23)$ & $(1.53)$ \\
\hline
\end{tabular}




\begin{tabular}{lcc}
\hline & Model 1 (SDROA) & Model 2 (VOL) \\
\hline \multirow{3}{*}{ F_INDBOD } & $(-0.23)$ & $(-1.02)$ \\
& 0.088 & -0.003 \\
Intercept & $(1.03)$ & $(-0.51)$ \\
& 0.798 & -3.317 \\
& $(0.03)$ & $(-1.57)$ \\
\hline
\end{tabular}

The table reports OLS coefficient estimates and dummy variables are included in the regression to control for year and industry differences. However, the results are not provided due to space constraints. All definitions of variables are listed in Table 3. *, **, *** indicate two-sided significance at the $1 \%, 5 \%$, and $10 \%$ levels, respectively.

Following Harjoto and Laksmana (2018), we also re-examine our main models by excluding firms in utility and telecommunication sector because inherently this industry has excessive risk taking. Finally, we check whether our results remain similar when control variables are removed. Table 8 shows that the results are consistent with our main results in Table 6.

Table 8. CSR and Risk Taking-Excluding utility and telecommunication industry. and control variables

\begin{tabular}{|c|c|c|c|c|}
\hline & \multicolumn{2}{|l|}{ Excluding industry } & \multicolumn{2}{|c|}{ Excluding control var. } \\
\hline & Model 1 (SDROA) & Model 2 (VOL) & Model 1 (SDROA) & Model 2 (VOL) \\
\hline \multirow[t]{2}{*}{ CSR } & $-0.066^{*}$ & $-0.009 * * *$ & $-0.077 * *$ & $-0.008 * * *$ \\
\hline & $(-1.90)$ & $(-2.92)$ & $(-2.15)$ & $(-2.89)$ \\
\hline \multirow[t]{2}{*}{ LEV } & $0.054^{*}$ & -0.002 & - & - \\
\hline & $(1.59)$ & $(-0.75)$ & & \\
\hline \multirow[t]{2}{*}{ GROWTH_SALES } & $0.024 * * *$ & 0.001 & - & - \\
\hline & $(2.74)$ & (1.63) & & \\
\hline \multirow[t]{2}{*}{ LNTA } & -0.000 & -0.000 & - & - \\
\hline & $(-0.27)$ & $(-0.51)$ & & \\
\hline \multirow[t]{2}{*}{ FAGE } & 0.000 & $0.000^{*}$ & - & - \\
\hline & $(0.08)$ & $(1.77)$ & & \\
\hline \multirow[t]{2}{*}{ F_BODSIZE } & -0.005 & -0.000 & - & - \\
\hline & $(-0.69)$ & $(-0.97)$ & & \\
\hline \multirow[t]{2}{*}{ F_INDBOD } & -0.033 & 0.007 & - & - \\
\hline & $(-0.45)$ & $(0.11)$ & & \\
\hline \multirow[t]{2}{*}{ Intercept } & 0.143 & 0.037 & 0.133 & 0.333 \\
\hline & $(1.43)$ & $(4.03)$ & $(5.65)$ & $(-16.77)$ \\
\hline year and industry & Included & Included & Included & Included \\
\hline Observation & 791 & 791 & 820 & 820 \\
\hline $\mathrm{R}$-squared & 0.045 & 0.030 & 0.405 & 0.028 \\
\hline
\end{tabular}

The table reports OLS coefficient estimates and dummy variables are included in the regression to control for year and industry differences. However, the results are not provided due to space constraints. All definitions of variables are listed in Table 3. *, $* *, * * *$ indicate two-sided significance at the $1 \%, 5 \%$, and $10 \%$ levels, respectively. 


\section{Conclusions}

Our paper investigates the effect of CSR on risk taking in Indonesia, including operating and market risk. Firms with CSR concern will consider the interests of various parties such as creditors, investors, government and society. In this case, companies need to be able to allocate their resources to both shareholders and other stakeholders. When company fails to address the needs of stakeholders, it will cause more risks or excessive risk. It is possible that stakeholders use their power to limit access to the resources they have controlled. Company with excessive risk aversion will be less attractive to shareholders and limit the availability of funds for future growth. However, when company focuses on the needs of stakeholders, it will be an effective way to reduce company's risks.

Based on listed companies in the IDX from 2016-2017, we find that CSR has an effect on operating and market risks in model 1 and model 2 . This finding suggests that CSR activity is an effective way to minimize corporate risks in emerging market context where the level of risks is high. Also, we address endogeneity issue by using GMM and the results are still consistent. However, the results of this study must be interpreted by considering several limitations. First, we utilize only total risk to measure risk, and do not specifically consider beta or systematic risk as a proxy. Second, we use one proxy for CSR index.

\section{References}

Abbott, L. J., Parker, S., and Presley, T. J. (2012). Female board presence and the likelihood of financial restatement. Accounting Horizons, 26(4), 607-629.

Acharya, V. V., Amihud, Y., and Litov, L. (2011). Creditor rights and corporate risk-taking. Journal of Financial Economics, 102(1), 150-166.

Ayadi, M., Kusy, M. I., Pyo, M., and Trabelsi, S. (2015). Corporate social responsibility, corporate governance, and managerial risk-taking. Corporate Governance, and Managerial Risk-Taking (January 9, 2015).

Bliss, M. A., and Gul, F. A. (2012). Political connection and cost of debt: Some Malaysian evidence. Journal of Banking and Finance, 36, 1520-1527.

Bradley, M., and Chen, D. (2014). Does board independence reduce the cost of debt? Financial Management, 44(1), 15-47.

Bova, F., and Pereira, R., (2012), "The Determinants and Consequences of Heterogenenous IFRS Compliance Levels Following Mandatory IFRS Adoption: Evidence from a Developing Country”, Journal of International Accounting Research11(1): 83-11

Centre for Governance, Institutions and Organisations (CGIO) (2016). In Southeast Asia, Corporate Governance Picks Up as a Norm, Conference on Corporate Governance and Responsibility: Theory Meets Practice. Retrieved from http://www.aseannews.net/southeast-asia-corporate-governance-picks-norm/.

Chakraborty, A., Gao, L. S., and Sheikh, S. (2019). Managerial risk taking incentives, corporate social responsibility and firm risk. Journal of Economics and Business, 101, 58-72.

Chollet, P., and Sandwidi, B. W. (2018). CSR engagement and financial risk: A virtuous circle? International evidence. Global Finance Journal, 38, 65-81.

Deegan, C. (2002). Introduction: the legitimising effect of social and environmental disclosures-a theoretical foundation. Accounting, Auditing and Accountability Journal, 15(3), 282-311.

Donaldson, T., and Preston, L. E. (1995). The stakeholder theory of the corporation: Concepts, evidence, and implications. Academy of management review, 20(1), 65-91.

European Commission (2010). A sustainable Europe for a better world: A European Union strategy for sustainable development. Brussels.

Faccio, M., Marchica, M.-T., and Mura, R. (2011). Large shareholder diversification and corporate risk-taking. The Review of Financial Studies, 24(11), 3601-3641.

Frynas, J. G. (2009). Beyond corporate social responsibility: Oil multinationals and social challenges (Vol. 10): Cambridge University Press Cambridge.

Global RepTrak 100. (2017). Retrieved from http://www.ideeideas.it/press/global_reptrak_2017.pdf

Gray, R., Owen, D., and Adams, C. (1996). Accounting and accountability: changes and challenges in corporate social and environmental reporting: Prentice Hall.

Harjoto, M., and Laksmana, I. (2018). The impact of corporate social responsibility on risk taking and firm value. Journal of business ethics, 151(2), 353-373.

Heal, G. (2005). Corporate social responsibility: An economic and financial framework. The Geneva papers on risk and insurance-Issues and practice, 30(3), 387-409.

Hillman, A. J., and Keim, G. D. (2001). Shareholder value, stakeholder management, and social issues: what's the bottom line? Strategic Management Journal, 22(2), 125-139.

Jo, H., and Na, H. (2012). Does CSR reduce firm risk? Evidence from controversial industry sectors. Journal of business ethics, 110(4), 441-456.

John, K., Litov, L., and Yeung, B. (2008). Corporate governance and risk-taking. The Journal of Finance, 63(4), $1679-1728$. 
Jones, T. M. (1995). Instrumental stakeholder theory: A synthesis of ethics and economics. Academy of management review, 20(2), 404-437.

Khan, A., Muttakin, M. B., and Siddiqui, J. (2013). Corporate governance and corporate social responsibility disclosures: Evidence from an emerging economy. Journal of business ethics, 114(2), 207-223.

Muttakin, M. B., and Khan, A. (2014). Determinants of corporate social disclosure: Empirical evidence from Bangladesh. Advances in accounting, 30, 168-175.

Nguyen, P. (2012). Corporate governance and risk-taking: Evidence from Japanese firms. Pacific-Basin Finance Journal, 19(3), 278-297.

Nguyen, P., and Nguyen, A. (2015). The effect of corporate social responsibility on firm risk. Social Responsibility Journal, 11(2), 324-339.

Pandey, R., Pallab B., Muhammad J. A., and Mansi M. (2018). Female Director on The Board and Cost of Debt: Evidence from Australia. Working Paper. Otogato University, Dunedin, New Zealand.

Salama, A., Anderson, K., and Toms, J. (2011). Does community and environmental responsibility affect firm risk? Evidence from UK panel data 1994-2006. Business Ethics: A European Review, 20, 192-204.

Sen, S., Bhattacharya, C.B. and Korschun, D. (2006). The role of corporate social responsibility in strengthening multiple stakeholder relationships. Journal of the Academy of Marketing Science, 34, 158-166.

Terjesen, S., Couto, E. B., and Francisco, P. M. (2016). Does the presence of independent and female directors impact firm performance? A multi-country study of board diversity. Journal of Management and Governance, 20(3), 447-483.

Usman, M., Farooq, M. U., Zhang, J., Makki, M. A. M., and Khan, M. K. (2019). Female directors and the cost of debt: does gender diversity in the boardroom matter to lenders? Managerial Auditing Journal, 34(4), 374-392.

Zhang, J. (2016). Does corporate social responsibility affect financial performance of listed manufacturing firms in Germany? , University of Twente.

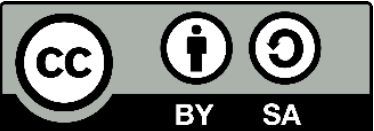

(C) 2019 by the authors. Licensee ACRN Publishing, Austria, Editor in Chief Prof. Dr. Othmar M. Lehner. This article is an open access article distributed under the terms and conditions of the Creative Commons Attribution (CC BY SA) license (https://creativecommons.org/licenses/by-sa/4.0/) 